\title{
NOTES
}

\section{A Phylogenetic Analysis of Aerobic Polychlorinated Biphenyl-Degrading Bacteria}

\author{
WILLIAM A. WILLIAMS, * JOHN H. LOBOS, AND WILLIAM E. CHEETHAM \\ GE Research and Development Center, Schenectady, New York 12301
}

\begin{abstract}
Several bacterial isolates were characterized based on their abilities to degrade specific polychlorinated biphenyls (PCBs) and their 16S rRNA gene sequences. The members of one group of bacteria consisting of Alcaligenes species, including the PCB-degrading bacterium Alcaligenes eutrophus H850, had strong abilities to degrade a broad range of PCBs but not the di-para-chlorine-substituted congeners. The members of another group, which included the PCB-degrading bacterium originally classified as Corynebacterium sp. strain MB1, had strong abilities to degrade di-para-chlorine-substituted PCBs. These bacteria were most likely different members of Rhodococcus species.
\end{abstract}

Aerobic microbial degradation of polychlorinated biphenyls (PCBs) is well documented and has been characterized at the genetic level for several bacterial isolates $(6,12,16,19)$. Various PCB-degrading bacteria isolated from PCB-contaminated Hudson River sediment have significant differences in their abilities to degrade various PCB congeners (8). However, very little is known about the identities or phylogenetic relatedness of these bacterial isolates. A phylogenetic classification of these bacteria would be useful for understanding the diversity of PCB-degrading microorganisms and possibly for identifying any correlation with PCB-degradative ability.

Current molecular biology techniques, in conjunction with Ribosomal Database Project (RDP) data, have permitted rapid classification of microorganisms and delineation of their evolutionary relationships $(11,18)$. Pseudomonas sp. strain LB400 (4) and Alcaligenes eutrophus H850 (3) have been shown to contain nearly identical genes coding for the PCB-degradative enzymes, which are different from the enzymes in Pseudomonas cepacia, Pseudomonas testosteroni, Alcaligenes faecalis, and Corynebacterium sp. strain MB1 $(14,19)$. In this paper, we report on a phylogenetic analysis of eight PCB-degrading bacterial isolates in which $16 \mathrm{~S}$ rRNA gene analysis was used. In addition, two isolates previously classified as Arthrobacter sp. strain M5 (7) and Corynebacterium sp. strain MB1 (3) are reclassified.

Bacterial strains 2AV, 2A2, 2A42, 6S48, and 2N40 (Table 1) were isolated from $\mathrm{PCB}-$ contaminated Hudson River sediment (8). A Biolog GN Microplate assay (Biolog, Inc., Haywood, Calif.) was used to characterize these isolates, in addition to PCB biodegradation and 16S rRNA gene phylogenetic analyses.

PCB biodegradation. Resting cell assays (2) were performed to examine the abilities of the different strains to degrade PCBs and determine if there is a correlation between the phylogenetic relationships of these organisms and their specific PCBdegradative abilities. The abilities of the various bacterial strains to degrade selected PCB congeners during resting cell assays are shown in Table 1 . The predominant mechanism of PCB degradation by the strains involves an initial 2,3-dioxyge-

\footnotetext{
* Corresponding author. Mailing address: GE Research and Development Center, P.O. Box 8, Schenectady, NY 12301.
}

nase attack, followed by a second dioxygenase oxidation that results in cleavage of one of the biphenyl rings (8). The primary products of this pathway are the corresponding chlorobenzoic acids, which are slowly metabolized by some of the strains, as well as various other bacteria in the environment.

Bacterial strains were grown in $20 \mathrm{ml}$ of a phosphate-ammonium salts (PAS) medium (2) in 50-ml shake flasks for 24 to $48 \mathrm{~h}$ at $30^{\circ} \mathrm{C}$ on a rotary incubator-shaker. Cells were harvested by centrifugation $(2,000 \times g)$ and resuspended in $50 \mathrm{mM}$ sodium phosphate buffer ( $\mathrm{pH} 7.4$ ) to an optical density at $615 \mathrm{~nm}$ $\left(A_{615}\right)$ of 1.0. Aliquots $(1 \mathrm{ml})$ were dispensed into 2-dram (ca. 7.4-ml) vials with Teflon-lined caps, and this was followed by the addition to each vial of $10 \mu \mathrm{l}$ of one of three different PCB congener stock mixtures dissolved in acetone as a $100 \times$-concentrated solution. Each PCB mixture contained 10 to 15 of the congeners shown in Table 1 and always included a nonbiodegradable PCB congener $\left(2,4,6,2^{\prime}, 4^{\prime}\right.$-chlorobiphenyl $\left.\left[2,4,6,2^{\prime}, 4^{\prime}-\mathrm{CB}\right]\right)$ which was used as an internal standard. The final concentration of each PCB congener in the culture medium was $5 \mu \mathrm{M}$. The resting cell assay mixtures in the 2-dram vials were incubated horizontally at $30^{\circ} \mathrm{C}$ for $24 \mathrm{~h}$ on a rotary incubator-shaker at $250 \mathrm{rpm}$. Killed culture controls were incubated in parallel; these controls contained $10 \mu \mathrm{l}$ of $70 \%$ perchloric acid before the PCBs were added. Each of the live assays was stopped by adding $10 \mu \mathrm{l}$ of $70 \%$ perchloric acid. All cultures were extracted in the same vials with $4 \mathrm{ml}$ of a 50:50 ether-hexane mixture by shaking them overnight on a reciprocating shaker. The PCB-containing solvent was removed and analyzed by gas chromatography with electron capture detection, using either a 30-m Durabond-1 capillary column ( $\mathrm{J} \& \mathrm{~W}$ Scientific) or a 30-m SB-Octyl-50 capillary column (Lee Scientific, Salt Lake City, Utah). The PCBs were quantified by normalization to the nonbiodegradable congener $\left(2,4,6,2^{\prime}, 4^{\prime}-\right.$ CB) after single-point calibration with the acid-killed control cultures.

Amplification, sequencing, and analysis of 16S rRNA genes. The DNA used as a template for amplification of the $16 \mathrm{~S}$ rRNA gene of each bacterial culture was obtained by cell lysis performed by repetitive freezing (solid $\mathrm{CO}_{2}$ ) and thawing $\left(80^{\circ} \mathrm{C}\right.$ water bath) in a $50 \mathrm{mM}$ Tris buffer titrated with EDTA to $\mathrm{pH} 7.8$. The nearly full-length $16 \mathrm{~S}$ rRNA gene of each strain was amplified from the cell lysate by performing a PCR with primers that match the ends of the $16 \mathrm{~S}$ rRNA genes of most 
TABLE 1. Biodegradation of selected PCB congeners by bacterial strains

\begin{tabular}{|c|c|c|c|c|c|c|c|c|}
\hline \multirow{2}{*}{ PCB congener } & \multicolumn{8}{|c|}{ \% Degradation by strain: } \\
\hline & $2 \mathrm{~A} 42$ & $2 \mathrm{~A} 2$ & $2 \mathrm{AV}$ & $\mathrm{H} 850$ & LB400 & $2 \mathrm{~N} 40$ & $6 \mathrm{~S} 48$ & MB1 \\
\hline $2,2^{\prime}-\mathrm{CB}$ & $98 \pm 2^{a}$ & $99 \pm 2$ & $100 \pm 0$ & $95 \pm 4$ & $98 \pm 5$ & $65 \pm 7$ & $74 \pm 1$ & $88 \pm 9$ \\
\hline $2,6-\mathrm{CB}$ & $12 \pm 5$ & $58 \pm 12$ & $47 \pm 3$ & $17 \pm 11$ & $31 \pm 8$ & $7 \pm 6$ & $11 \pm 2$ & $36 \pm 5$ \\
\hline $2,4^{\prime}-\mathrm{CB}$ & $96 \pm 4$ & $98 \pm 3$ & $100 \pm 0$ & $99 \pm 2$ & $98 \pm 1$ & $100 \pm 0$ & $100 \pm 0$ & $100 \pm 0$ \\
\hline $2,3,2^{\prime}-\mathrm{CB}$ & $90 \pm 9$ & $93 \pm 6$ & $82 \pm 7$ & $87 \pm 5$ & $89 \pm 5$ & $41 \pm 6$ & $11 \pm 2$ & $69 \pm 6$ \\
\hline $2,4,2^{\prime}-\mathrm{CB}$ & $86 \pm 12$ & $91 \pm 5$ & $79 \pm 7$ & $96 \pm 1$ & $95 \pm 2$ & $10 \pm 9$ & $11 \pm 3$ & $16 \pm 2$ \\
\hline $2,5,2^{\prime}-\mathrm{CB}$ & $92 \pm 5$ & $93 \pm 5$ & $83 \pm 3$ & $97 \pm 2$ & $97 \pm 2$ & $96 \pm 8$ & $88 \pm 8$ & $69 \pm 3$ \\
\hline $2,5,4^{\prime}-\mathrm{CB}$ & $84 \pm 3$ & $78 \pm 11$ & $77 \pm 6$ & $94 \pm 2$ & $98 \pm 2$ & $99 \pm 1$ & $91 \pm 2$ & $98 \pm 2$ \\
\hline $2,6,2^{\prime}-\mathrm{CB}$ & $9 \pm 6$ & $50 \pm 11$ & $45 \pm 3$ & $26 \pm 8$ & $43 \pm 11$ & 0 & $10 \pm 2$ & $9 \pm 5$ \\
\hline $2,6,3^{\prime}-\mathrm{CB}$ & $37 \pm 6$ & $81 \pm 7$ & $67 \pm 6$ & $89 \pm 4$ & $95 \pm 2$ & $13 \pm 10$ & $8 \pm 2$ & $100 \pm 1$ \\
\hline $2,6,4^{\prime}-\mathrm{CB}$ & $12 \pm 3$ & $29 \pm 9$ & $30 \pm 3$ & $15 \pm 7$ & $23 \pm 8$ & 0 & 0 & 0 \\
\hline $2,3,2^{\prime}, 3^{\prime}-\mathrm{CB}$ & $58 \pm 12$ & $70 \pm 7$ & $57 \pm 5$ & $95 \pm 4$ & $97 \pm 2$ & $27 \pm 5$ & 0 & $100 \pm 0$ \\
\hline $2,3,2^{\prime}, 5^{\prime}-\mathrm{CB}$ & $76 \pm 11$ & $76 \pm 8$ & $59 \pm 5$ & $95 \pm 4$ & $98 \pm 2$ & $86 \pm 6$ & $40 \pm 2$ & $83 \pm 4$ \\
\hline $2,5,3^{\prime}, 4^{\prime}-\mathrm{CB}$ & $61 \pm 7$ & $57 \pm 14$ & $58 \pm 7$ & $85 \pm 10$ & $91 \pm 3$ & $84 \pm 13$ & $61 \pm 12$ & $43 \pm 3$ \\
\hline $4,4^{\prime}-\mathrm{CB}$ & $44 \pm 9$ & 0 & $12 \pm 7$ & $27 \pm 12$ & $39 \pm 8$ & $100 \pm 0$ & $50 \pm 3$ & $100 \pm 0$ \\
\hline $2,4,4^{\prime}-\mathrm{CB}$ & $16 \pm 7$ & $15 \pm 4$ & $24 \pm 4$ & $54 \pm 10$ & $89 \pm 9$ & $98 \pm 3$ & $42 \pm 1$ & $100 \pm 0$ \\
\hline $2,4,2^{\prime}, 4^{\prime}-\mathrm{CB}$ & 0 & 0 & 0 & $45 \pm 13$ & $93 \pm 5$ & 0 & 0 & 0 \\
\hline $2,4,3^{\prime}, 4^{\prime}-\mathrm{CB}$ & 0 & 0 & $8 \pm 2$ & $14 \pm 3$ & $59 \pm 15$ & $46 \pm 9$ & 0 & $87 \pm 3$ \\
\hline $3,4,3^{\prime}, 4^{\prime}-\mathrm{CB}$ & 0 & 0 & 0 & 0 & 0 & 0 & 0 & $6 \pm 2$ \\
\hline $2,5,2^{\prime}, 5^{\prime}-\mathrm{CB}$ & $70 \pm 12$ & $69 \pm 10$ & $51 \pm 5$ & $89 \pm 8$ & $93 \pm 4$ & 0 & 0 & $8 \pm 1$ \\
\hline $2,4,5,2^{\prime}, 3^{\prime}-\mathrm{CB}$ & $21 \pm 5$ & 0 & $12 \pm 3$ & $43 \pm 9$ & $81 \pm 9$ & 0 & 0 & $88 \pm 4$ \\
\hline $2,4,5,2^{\prime}, 5^{\prime}-\mathrm{CB}$ & $32 \pm 9$ & $21 \pm 6$ & $23 \pm 3$ & $71 \pm 9$ & $88 \pm 4$ & 0 & 0 & 0 \\
\hline $2,3,4,2^{\prime}, 5^{\prime}-\mathrm{CB}$ & $32 \pm 8$ & $26 \pm 7$ & $28 \pm 2$ & $62 \pm 16$ & $88 \pm 9$ & 0 & 0 & 0 \\
\hline $2,4,5,2^{\prime}, 4^{\prime}, 5^{\prime}-\mathrm{CB}$ & 0 & 0 & 0 & $22 \pm 6$ & $61 \pm 15$ & 0 & 0 & 0 \\
\hline
\end{tabular}

${ }^{a}$ Average $\pm 95 \%$ confidence interval, calculated from four to seven separate resting cell assays.

bacteria (primers fD1 and rP2 as described by Weisburg et al. [17]). The PCR was performed by using a GeneAmp kit and the hot-start technique with Ampliwax beads as recommended by the manufacturer (Perkin-Elmer Cetus, Norwalk, Conn.). Regions of the $16 \mathrm{~S}$ rRNA gene were sequenced by using primers complementary to the ends of the gene and two primers complementary to one of the hybridizing sites (Escherichia coli 16 S rRNA positions 519 to 536) of the "universal" smallsubunit rRNA primers (10). Between 190 and 230 bases of DNA sequence were determined twice for each of the four regions of the $16 \mathrm{~S}$ rRNA genes that were sequenced. Approximately 780 and 880 unambiguous positions of the total gene $(\sim 50 \%$ of the gene) were used for phylogenetic analyses of the gram-negative and gram-positive isolates, respectively. DNA sequencing was performed by labeling the PCR primers with $\left[\gamma-{ }^{32} \mathrm{P}\right] \mathrm{ATP}$ and using an AmpliTaq cycle sequencing kit (Perkin-Elmer Cetus). The DNA sequences were aligned, and phylogenetic analyses using parsimony (computer analysis of the data using PAUP 3.1.1 software) were performed for sections of the 16S rRNA genes of the isolates used in this study and species in the RDP database (11).

Comparison of the DNA sequences and the PCB-degrading abilities of the bacterial strains. Degradation of specific PCB congeners is one method by which PCB-degrading environmental isolates are distinguished. Using a resting cell assay for discriminating PCB-degrading ability, Bedard et al. (2) concluded that strains $\mathrm{H} 850$ and LB400 have superior PCB-degradative abilities. Table 1 shows that bacterial isolates $2 \mathrm{~A} 42$, $2 \mathrm{~A} 2$, and $2 \mathrm{AV}$ differ slightly from each other, H850, and LB400 in their abilities to degrade PCB congeners containing di-ortho-chlorines (2,6-CB, 2,6,4'-CB, etc.), di-para-chlorines $\left(4,4^{\prime}-\mathrm{CB}, 2,4,2^{\prime}, 4^{\prime}-\mathrm{CB}\right.$, etc.), and penta- and hexachlorines (8). All these bacterial strains degrade an unusually broad range of PCB congeners compared with most other isolates and are grouped in a class with $\mathrm{H} 850$ and LB400 based on their biphenyl dioxygenase activity (1). In particular, the inabilities of $2 \mathrm{~A} 42,2 \mathrm{~A} 2$, and $2 \mathrm{AV}$ to degrade di-para-chlorinated congeners (i.e., 4,4'-CB and 2,4,4'-CB) compared with the degradation observed with strains $2 \mathrm{~N} 40,6 \mathrm{~S} 48$, and MB1 distinguish $2 \mathrm{~A} 42$, $2 \mathrm{~A} 2$, and $2 \mathrm{AV}$ as "H850-like" bacteria.

The PCB-degradative ability of strain MB1 has placed this bacterium in a class separate from $\operatorname{H850}(1,3)$. This distinction is made on the basis of the ability of MB1 to degrade $4,4^{\prime}-\mathrm{CB}$ and $2,4,4^{\prime}-\mathrm{CB}$ to a greater extent than H850 and LB400 degrade them and its inability to degrade $2,5,2^{\prime}, 5^{\prime}-\mathrm{CB}$. Therefore, the extensive degradation of $4,4^{\prime}-\mathrm{CB}$ and $2,4,4^{\prime}-\mathrm{CB}$ by strains 6S48 and 2N40 (Table 1) distinguishes these organisms from the H850-like strains and puts them in a class with MB1 ("MB1-like" bacteria), even though their PCB-degradative abilities are not as great as that of MB1. This grouping is also supported by the studies of the biphenyl dioxygenase operon performed by Ritchie and coworkers, who demonstrated by using nucleic acid hybridization that $2 \mathrm{~A} 2$ has a biphenyl dioxygenase cluster of genes that are very similar to the genes in LB400 and H850 and very distinct from the genes in MB1 and the MB1-like bacteria (14).

The PCR products from amplification of the 16S rRNA genes of isolates $2 \mathrm{~A} 42,2 \mathrm{~A} 2,2 \mathrm{AV}, 6 \mathrm{~S} 48$, and $2 \mathrm{~N} 40, A$. eutrophus H850 (3), Corynebacterium sp. strain MB1 (3), and $A r$ throbacter sp. strain M5 (7) were analyzed and purified by electrophoresis in an agarose gel. The expected $\sim 1,500$-bp $16 \mathrm{~S}$ rRNA gene of each microorganism was observed. In addition, an $\sim 1,100$-bp band was observed with isolates $2 \mathrm{~A} 42,2 \mathrm{~A} 2$, and $2 \mathrm{AV}$, which suggests that these bacteria are more closely related to each other than to H850.

The DNA sequences of regions of the 16S rRNA gene of each of the bacterial isolates provided data about how the microorganisms are related to each other and to bacteria in the RDP database. The 16S rRNA gene sequence of $A$. eutrophus H850 (3) was nearly the same (level of similarity, 99\%) as the sequence of $A$. eutrophus in the RDP database (11). The H850like isolates $(2 \mathrm{AV}, 2 \mathrm{~A} 2$, and $2 \mathrm{~A} 42)$ had identical DNA sequences. Hence, it is likely that these organisms are different strains of the same bacterial species. A comparison of the $16 \mathrm{~S}$ 


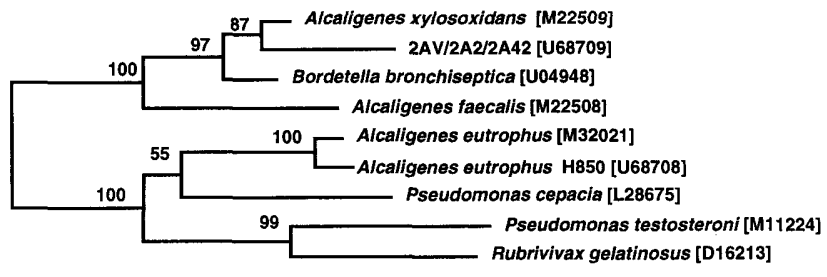

$5 \%$ difference

FIG. 1. Phylogenetic tree based on partial 16S rRNA gene sequences of $\mathrm{H} 850$ and the H850-like gram-negative bacteria in the $\beta$ subdivision of the Proteobacteria. The H850-like bacteria (strains 2AV, 2A2, and 2A42) are listed together because their DNA sequences were identical. This tree is midpoint rooted and is a consensus tree based on 500 parsimony bootstrap replicates. The percentage of replicates supporting a given branch point is indicated to the left of the branch point. The lengths of the branches are related to the differences between the DNA sequences. Comparisons were made by using $\sim 780$ unambiguous positions. GenBank nucleotide sequence accession numbers are indicated in brackets.

rRNA gene sequences of $\mathrm{H} 850,2 \mathrm{~A} 42,2 \mathrm{~A} 2$, and $2 \mathrm{AV}$ with sequences in the RDP database indicated that each strain is most similar to members of the $\beta$ subdivision of the Proteobacteria (purple bacteria). A comparison of the $16 \mathrm{~S}$ rRNA gene sequences of MB1, 6S48, and 2N40 with sequences in the RDP database indicated that MB1, 6S48, and 2N40 are most similar to members of the high-G+C-content subdivision of the grampositive bacteria.

The DNA sequences of the 16S rRNA genes of Corynebacterium sp. strain MB1 and Arthrobacter sp. strain M5 were identical. Bedard and coworkers (3) could not rule out the possibility that these bacteria were identical since Arthrobacter and Corynebacterium species have similar characteristics according to Bergey's Manual of Systematic Bacteriology (5) and both were isolated from the same coculture containing Acinetobacter sp. strain P6. In contrast, Péloquin and Greer concluded that Arthrobacter sp. strain M5 is an Arthrobacter sp. and not a Corynebacterium sp. because they observed that it had a rod-coccus cell cycle (13). The data from this study and the data of Bedard et al. (3) suggest that MB1 and M5 are members of the same genus and quite possibly the same species.

Phylogenetic analysis of $\mathbf{H 8 5 0}$ and the H850-like bacteria. A phylogenetic analysis of the 16S rRNA data for strain H850, the H850-like bacteria, and selected species belonging to the $\beta$ subdivision of the Proteobacteria produced the dendrogram shown in Fig. 1. This comparison was made to determine the species in the eubacterial kingdom to which H850 and the H850-like bacteria are most closely related and to determine how closely the two taxa are related to each other. The phylogenetic analysis (Fig. 1) indicated that the H850-like bacteria are more closely related to Alcaligenes xylosoxidans than to $A$. eutrophus. This result is in agreement with the results of the biochemical analyses of the H850-like bacteria that were performed with the Biolog GN Microplate assay; this assay revealed that some of the H850-like bacteria were a very good or excellent match with $A$. xylosoxidans subsp. denitrificans. In addition, the dendrogram in Fig. 1 is very similar to a dendrogram in the section on the genus Alcaligenes in Bergey's Manual (9). The data used to produce the dendrogram in Bergey's Manual was obtained from thermal denaturation curves for DNA-rRNA hybrids of the rRNA cistrons.

Phylogenetic analysis of MB1 and the MB1-like bacteria. A phylogenetic analysis of the 16S rRNA data for MB1 and M5, the MB1-like bacteria, and selected species belonging to the high-G+C-content subdivision of the gram-positive bacteria in

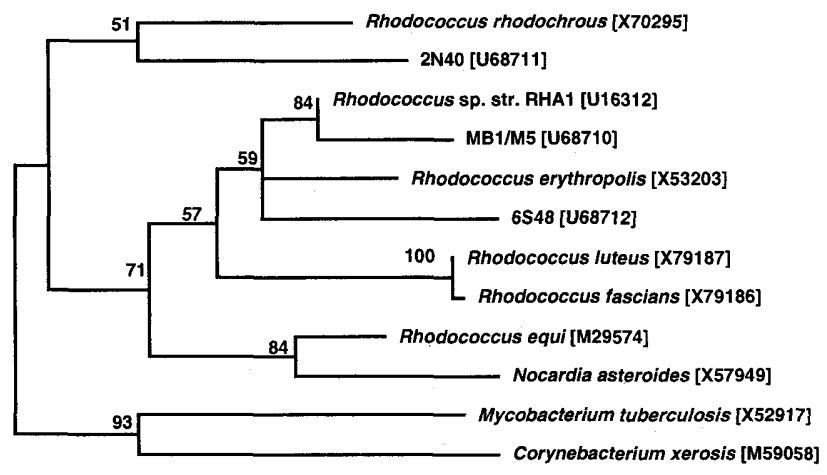

$3 \%$ difference

FIG. 2. Phylogenetic tree based on partial 16S rRNA gene sequences of strains MB1 and M5 and the MB1-like bacteria in the high-G+C-content subdivision of the gram-positive bacteria. Strains MB1 and M5 are listed together because their DNA sequences were identical. This tree was prepared in the same fashion as the tree in Fig. 1 . Comparisons were made by using $\sim 880$ unambig uous positions.

the RDP database resulted in the dendrogram shown in Fig. 2. We determined that MB1, M5, 6S48, and 2N40 are closely related to several species of the genus Rhodococcus. In particular, MB1 and M5 are most closely related to another PCBdegrading isolate, Rhodococcus sp. strain RHA1 $(12,15)$. Seto et al. (15) reported that RHA1 exhibits good degradation activity with both ortho- and para-chlorine-substituted PCB congeners, which is comparable to the PCB-degradative activities of MB1 and the other MB1-like bacteria (Table 1). From this phylogenetic analysis, we concluded that MB1, M5, 6S48, and 2N40 are not members of Corynebacterium or Arthrobacter species but instead are members of Rhodococcus species.

The PCB-degrading bacteria isolated from Hudson River sediment and described in this report can be classified into two groups based on their abilities to degrade specific PCB congeners. The biochemical characteristics and the DNA sequences of the 16S rRNA genes of these isolates also put them in two different genera, Alcaligenes and Rhodococcus. Strain H850 and the H850-like isolates, which have strong abilities to degrade a broad range of congeners but not the di-para-chlorinesubstituted PCBs, are members of the genus Alcaligenes. Strain MB1 and the MB1-like isolates, which have strong abilities to degrade di-para-chlorine-substituted PCBs, appear to be members of Rhodococcus species. A consistency was observed with the criteria used, which suggests that the members of each of the two groups of bacteria contain distinct enzyme activities for specific PCB congeners. Further understanding of the evolutionary relationship of these groups might provide insight on the evolutionary relationship of their PCB-degradative abilities.

Nucleotide sequence accession numbers. The sequences of regions of $16 \mathrm{~S}$ rRNA genes determined in this study have been deposited in the GenBank database under the following accession numbers: $A$. eutrophus H850, U68708; strains 2AV, 2A2, and 2A42, U68709; strains MB1 and M5, U68710; strain 2N40, U68711; and strain 6S48, U68712.

We thank Kensuke Furukawa for kindly providing Arthrobacter sp. strain M5.

\section{REFERENCES}

1. Bedard, D. L., and M. L. Haberl. 1990. Influence of chlorine substitution pattern on the degradation of polychlorinated biphenyls by eight bacterial strains. Microb. Ecol. 20:87-102. 
2. Bedard, D. L., R. Unterman, L. H. Bopp, M. J. Brennan, M. L. Haberl, and C. Johnson. 1986. Rapid assay for screening and characterizing microorganisms for the ability to degrade polychlorinated biphenyls. Appl. Environ. Microbiol. 51:761-768.

3. Bedard, D. L., R. E. Wagner, M. J. Brennan, M. L. Haberl, and J. F. Brown, Jr. 1987. Extensive degradation of Aroclors and environmentally transformed polychlorinated biphenyls by Alcaligenes eutrophus H850. Appl. Environ. Microbiol. 53:1094-1102.

4. Bopp, L. H. 1986. Degradation of highly chlorinated PCBs by Pseudomonas strain LB400. J. Ind. Microbiol. 1:23-29.

5. Collins, M. D., and C. S. Cummins. 1986. Genus Corynebacterium, p. 12661273. In P. H. A. Sneath, N. S. Mair, M. E. Sharpe, and J. G. Holt (ed.) Bergey's manual of systematic bacteriology, vol. 2. The Williams and Wilkins Co., Baltimore, Md.

6. Erickson, B. D., and F. J. Mondello. 1992. Nucleotide sequencing and transcriptional mapping of the genes encoding biphenyl dioxygenase, a multicomponent polychlorinated-biphenyl-degrading enzyme in Pseudomonas strain LB400. J. Bacteriol. 174:2903-2912.

7. Furukawa, K., and A. M. Chakarbarty. 1982. Involvement of plasmids in total degradation of chlorinated biphenyls. Appl. Environ. Microbiol. 44: 619-626.

8. Harkness, M. R., J. B. McDermott, D. A. Abramowicz, J. J. Salvo, W. P. Flanagan, M. L. Stephens, F. J. Mondello, R. J. May, J. H. Lobos, K. M. Carroll, M. J. Brennan, A. A. Bracco, K. M. Fish, G. L. Warner, P. R. Wilson, D. K. Dietrich, D. T. Lin, C. B. Morgan, and W. L. Gately. 1993. In situ stimulation of aerobic PCB biodegradation in Hudson River sediments. Science 259:503-507.

9. Kersters, K., and J. De Ley. 1984. Genus Alcaligenes, p. 361-373. In N. R Krieg and J. G. Holt (ed.), Bergey's manual of systematic bacteriology, vol. 1. The Williams and Wilkins Co., Baltimore, Md.

10. Lane, D. J., B. Pace, G. J. Olsen, D. A. Stahl, M. L. Sogin, and N. R. Pace. 1985. Rapid determination of 16S ribosomal RNA sequences for phyloge- netic analysis. Proc. Natl. Acad. Sci. USA 82:6955-6959.

11. Maidak, B. L., N. Larsen, M. J. McCaughey, R. Overbeek, G. J. Olsen, K. Fogel, J. Blandy, and C. R. Woese. 1994. The Ribosomal Database Project. Nucleic Acids Res. 22:3485-3487.

12. Masai, E., A. Yanada, J. M. Healy, T. Hatta, K. Kimbara, M. Fukuda, and K. Yano. 1995. Characterization of biphenyl catabolic genes of gram-positive polychlorinated biphenyl degrader Rhodococcus sp. strain RHA1. Appl. Environ. Microbiol. 61:2079-2085.

13. Péloquin, L., and C. W. Greer. 1993. Cloning and expression of the polychlorinated biphenyl-degradation gene cluster from Arthrobacter M5 and comparison to analogous genes from gram-negative bacteria. Gene 125:3540.

14. Ritchie, K. B., J. H. Dennis, W. M. Randolph, F. J. Mondello, B. D. Erickson, J. H. Lobos, and J. R. Yates. 1993. Analysis of $b p h$ A genes related to Pseudomonas strain LB400, p. 225-232. In General Electric Company Research and Development Program for the Destruction of PCBs, Twelfth Progress Report. General Electric Corporate Research and Development, Schenectady, N.Y.

15. Seto, M., K. Kimbara, M. Shimura, T. Hatta, M. Fukuda, and K. Yano. 1995. A novel transformation of polychlorinated biphenyls by Rhodococcus sp. strain RHA1. Appl. Environ. Microbiol. 61:3353-3358.

16. Taira, K., J. Hirose, S. Hayashida, and K. Furukawa. 1992. Analysis of $b p h$ operon from the polychlorinated biphenyl-degrading strain of Pseudomonas pseudoalcaligenes KF707. J. Biol. Chem. 267:4844-4852.

17. Weisburg, W. G., S. M. Barns, D. A. Pelltier, and D. J. Lane. 1991. 16S ribosomal DNA amplification for phylogenetic study. J. Bacteriol. 173:697703 .

18. Woese, C. R. 1987. Bacterial evolution. Microbiol. Rev, 51:221-271.

19. Yates, J. R., and F. J. Mondello. 1989. Sequence similarities in the genes encoding polychlorinated biphenyl degradation by Pseudomonas strain LB400 and Alcaligenes eutrophus H850. J. Bacteriol. 171:1733-1735. 